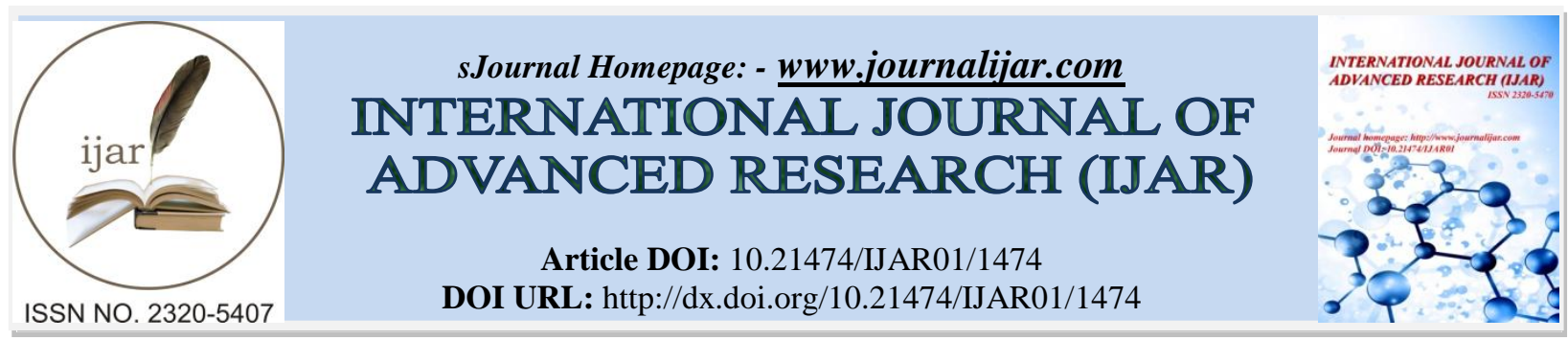

RESEARCH ARTICLE

\title{
HEPATOPROTECTIVE EFFECTS OF AGED GARLIC AND ETHANOLIC GINGER EXTRACTS IN MICE.
}

Romany Helmy Thabet ${ }^{1}$, Alanazi, Omar Qurayti $\mathrm{S}^{2}$, Alanazi, Abdulaziz Ahmed $\mathrm{N}^{2}$, Albejawi, Abdulrahman Mohammed $^{2}$, Alanazi, Meshari Hani $\mathrm{O}^{2}$, Albeqami,Mahdee Hemaidan², Alduraywish, Ibrahim Sulaiman ${ }^{2}$, Alenazi , Abdulaziz Mharb $^{\mathrm{H} 2}$, Alesa Abdulmihsin Ibrahim $\mathrm{O}^{2}$, Albeity, Bader Ahmad $\mathrm{H}^{2}$.

1 Assistant Prof. of pharmacology, Northern Border University, Arar, Saudi Arabia. 2 Medical Student, faculty of medicine, Jordan University of Science and Technology, Jordan

\section{Manuscript Info}

\section{Manuscript History}

Received: 12 July 2016

Final Accepted: 19 August 2016

Published: September 2016

\section{Key words:-}

Acetaminophen, alanine aminotransferase garlic, ginger, glutathione

\section{Abstract}

\begin{abstract}
Acetaminophen (APAP) is a widely used over-the-counter analgesic and antipyretic drug. .At large doses, it produces a fatal hepatic necrosis that accounts for acute liver failure. The present study investigates the potential protective effect of prior administration of ethanolic ginger and aged garlic extracts against acetaminopheninduced hepatic injury. Liver glutathione (GSH) and serum levels of alanine aminotransferase (ALT) and bilirubin were measured from groups of mice given APAP alone, orally as a suspension in distilled water in a dose of $500 \mathrm{mg} / \mathrm{kg}$, after prior pretreatment with oral 250 and $500 \mu$ gof ginger extract/d in $1.1 \%$ alcohol and after prior intraperitoneal administration of aged garlic extract in dose of 100 and $200 \mathrm{mg} / \mathrm{kg}$. The present study showed that significant improvement ( $p<0.05$ ) of both hepatic glutathione levels and serum levels of ALT and bilirubin in mice after prior administration of either ethanolic ginger extract or aged garlic extract each alone or in combination with each other compared with mice given APAP alone (in which hepatic GSH was significantly decreased and serum ALT and bilirubin were significantly increased, $\mathrm{p}<0.05$ ). The present work suggests that both ethanolic ginger extract and aged garlic possess hepatoprotective effects against acetaminophen-induced hepatic injury in mice.
\end{abstract}

Copy Right, IJAR, 2016,. All rights reserved.

\section{Introduction:-}

Acetaminophen (APAP) is an effective analgesic and antipyretic agent. It is safer compared with non-steroidal antiinflammatory drugs if used as directed by the physician. However, if used in large doses, APAP may cause serious liver injury. That leads to acute liver failure (1-2). APAP hepatic injury has been explained by the formation of Nacetyl-p-benzoquinone imine (NAPQI) in the liver that causes oxidative stress by depletion of the antioxidant glutathione. Additionally, NAPQI binds to important mitochondrial proteins causing necrosis of liver cells and release of inflammatory cytokines (3-4).

Use of natural antioxidants in food nowadays is considered to be a promising alternative for synthetic antioxidants owing to its low cost, high compatibility with dietary intake and harmless effects. Garlic and ginger are health 
protecting foods that contain rich amount of beneficial antioxidants. Garlic has long been used for hypertension and diabetes (5-7). It is owed to its antioxidant/anti-inflammatory and neuroprotective activities. Aged garlic extracts (AGE), compared with fresh garlic preparations, has no odor, contains higher quantities of antioxidants and protects against cancer, many cardiovascular diseases, stroke, Alzheimer's disease and other aging disorders (8). To get higher quantities of antioxidants, AGE is prepared by extracting and aging fresh garlic at room temperature for about one and half years in $20 \%$ ethanol. AGE contains flavonoids, allixin, selenium and water-soluble sulfur antioxidant substances with high bioavailability such as S-allylmercaptocysteine (SAMC) and S-allyl cysteine (SAC) (9-10).

Ginger is used in many foods and beverages. Ginger oil that comprises $1-3 \%$ of its weight contains a high percentage of hydrocarbons, mainly zingiberene, bisapolene, and zingiberol (11-13). It is used in traditional medicine since thousands of years in many countries like China and India for relieve of some clinical conditions e.g. nausea, headache, colds and rheumatic disorders (14). Additionally, is used in China for cold extremities and after blood loss to resuscitate the patient (15). Ginger also has a beneficial in treatment of gastric ulcers (16-17). Recent studies in literature revealed that ginger has an anti-oxidative stress activity and neuroprotective effects that may be due to an influence on inhibitory and excitatory neurotransmitters, and calcium channel inhibition (18-21).A study by Vishwakarma and his colleagues suggested that the benzene fraction of a petroleum ether extract of dried rhizomes of ginger has anticonvulsant, anxiolytic, antiemetic,sedative and analgesic activities(22-23).

The present study aims at investigating the potential beneficial effects of both AGE and ethanolic ginger extracts in protection against APAP-induced hepatic injury in mice by measuring the hepatic content of the antioxidant glutathione in addition to serum levels of the liver enzyme Alanine aminotransferase (ALT) and bilirubin that increase between 24 and 72 hours following exposure to an overdose of APAP.

\section{Materials and Methods:-}

\section{Chemicals and kits:-}

APAP tablet (Panadol®) suspended in freshly prepared distilled water (DW). Based on literature (24-25), oral median lethal dose (LD50) of APAP in mice equals $400-900 \mathrm{mg} / \mathrm{kg}$ thus $500 \mathrm{mg} / \mathrm{kgAPAP}$ was used to induce hepatic injury in mice. .Hepatic glutathione (GSH) was measured by using GSH Assay Kit (Cayman Chemical Company, United States).

\section{Animals:-}

Male mice (5 weeks) weighting 20-30 grams were acclimatized for one week in at room temperature $\left(23 \pm 3^{\circ} \mathrm{c}\right)$ on a 12-hours light-dark cycle and were fed ad libitum.

\section{Preparation of ethanolic extract of ginger:-}

According to the method described by Fuhrman and his colleagues, a stock solution was prepared by dissolving 200 $\mathrm{mg}$ of ginger extractin $44 \mathrm{~mL}$ of ethanol and then adjusted to $200 \mathrm{~mL}$ with $\mathrm{DW}$. A concentration of $50 \mathrm{mg} / \mathrm{L}$ of ginger extract in $1.1 \%$ alcohol and water was prepared by dilution of $25 \mathrm{~mL}$ of the ginger extract stock solution into $500 \mathrm{~mL}$ of DW (26).

\section{Preparation of aged garlic extracts (AGE):-}

Following method described Fatemeh and her colleagues, garlic bulbs were peeled and minced in an aqueousalcoholic solution and maintained for 18 months in anaerobic conditions. The aged garlic was then crushed using mortar and pestle and homogenized in DW. Using Whatman paper No. 1, the prepared homogenized aged garlic was filtered and then centrifuged to get the cleared supernatant. A stock solution400mggarlic /mlDW was prepared (27).

\section{Experimental protocol:-}

After acclimatization for one week, micewere randomly divided into 7 groups 10 animals each. Control group was given $0.5 \mathrm{mlDW}$ orally by intragastric tube. APAP was given to the $2^{\text {nd }}$ group orally, as a $0.5 \mathrm{ml}$ suspension in DW in a dose of $500 \mathrm{mg} / \mathrm{kgonce}$. To the $3^{\text {rd }}$ and $4^{\text {th }}$ groups $250 \mu \mathrm{g}$ and $500 \mu \mathrm{g}$, respectively, of ginger extract in $1.1 \%$ alcohol and water and APAP in a dose of $500 \mathrm{mg} / \mathrm{kg}$ once. The $5^{\text {th }}$ and $6^{\text {th }}$ mice groups were given intraperitoneally $100 \mathrm{mg} / \mathrm{kg}$ and $200 \mathrm{mg} / \mathrm{kg}$, respectively of AGEand APAP in a dose of $500 \mathrm{mg} / \mathrm{kg}$. A combination of $500 \mu$ gginger extract in $1.1 \%$ alcohol and waterand $200 \mathrm{mg} / \mathrm{kgAGE}$ in addition to APAP in a dose of $500 \mathrm{mg} / \mathrm{kg}$ was given to mice of the $7^{\text {th }}$ group. 


\section{Measurement of Alanine aminotransferase levels:-}

Fasting blood was obtained by decapitationand collected from each mouse into in EDTA-collecting tubes, and then centrifuged at $1,200 \times \mathrm{g}$ for $5 \mathrm{~min}$ at room temperature to obtain the serum sample, which was stored frozen at $-20^{\circ} \mathrm{C}$ until analyzed. Alanine aminotransferase (ALT) was determined by method of Reitman and Frankel (28).

\section{Measurement of total bilirubin levels:-}

Total plasma bilirubin levels were measured following protocoldescribed byBortolussiet al. according to methodology of Doumasand his colleagues (29-30). Dilution of a stock solution of bilirubin (20 mg/dl) in BSA (4 g/dl)was prepared to perform standard curves. Absorbance values at $600 \mathrm{~nm}$ were obtained by using a multiplate reader (LD 400C Luminescence Detector, Italy).

\section{Measurement of hepatic glutathione (GSH):-}

Twenty-four hours following administration of APAP either alone or with ethanolic ginger or AGE, the liver was removed to determine hepatic hepatic glutathione (GSH) following methodology described by Werawatganonand his colleagues (31) using Cayman' GSH assay kit which utilizes a carefully optimized recycling method, using GSH reductase, for the quantification of GSH. The sulfhydryl group of GSH reacts with 5, 5'-ditrio-bis-(2-nitrobenzoic acid) (DTNB), or Ellman's reagent and produces a yellow colored 5-thio-2nitrobenzoic acid (TNB). The mixed disulfide, GSTNB (between GSH and TNB) is reduced by GSH reductase to recycle the GSH and produce more TNB. The production of TNB is directly proportional to this recycling reaction which is in turn directly proportional to the concentration of GSH in the sample. The optical density of TNB is then measured at $405-414 \mathrm{~nm}$ using a microplate reader, which provides an accurate estimation of GSH in the sample.

\section{Statistical analysis:-}

Data of the present work are presented as mean \pm SE. One-way analysis of variance(ANOVA) was used to test groups' differences (Statistical significance was considered at $\mathrm{p}<0.05$ ) by using SPSS version 22.

\section{Results:-}

Alanine aminotransferase levels:-

The present work observed that serum ALT was significantly increased(237.6 $\pm 2.87 \mathrm{U} / \mathrm{L}$ vs51.25 $\pm 2.72 \mathrm{U} / \mathrm{L}$, $\mathrm{p}<0.05$ ) in the positive control group (given APAP) compared with the negative control group ( given DW ). Compared with positive control group, serum levels of ALT were lowered significantly in groups given ginger extracts in doses of 250 and $500 \mu \mathrm{g}$ with APAP $(60.12 \pm 2.41 \mathrm{U} / \mathrm{L}$ and $55.2 \pm 2.32 \mathrm{U} / \mathrm{L}$ vs237.6 $\pm 2.87 \mathrm{U} / \mathrm{L}$, p $<$ 0.05, respectively). Similarly, ALT levels in sera of mice given AGE in doses of 100 and $200 \mathrm{mg} / \mathrm{kg}$ were significantly lower compared with levels in mice given APAP alone (56. $2 \pm 1.88 \mathrm{U} / \mathrm{Land} 53.1 \pm 2.1 \mathrm{U} / \mathrm{L}$ vs237.6 $\pm 2.87 \mathrm{U} / \mathrm{L}, \mathrm{p}<0.05$, respectively. Combination of $500 \mu \mathrm{g}$ ginger extract and $200 \mathrm{mg} / \mathrm{kg} \mathrm{AGE}$ significantly improved ALT levels in mice given APAP $(52.3 \pm 2.2 \mathrm{U} / \mathrm{Lvs} 237.6 \pm 2.87 \mathrm{U} / \mathrm{L}, \mathrm{p}<0.05$.

\begin{tabular}{|c|c|c|c|}
\hline $\begin{array}{l}\text { Animal group } \\
(\mathrm{n}=10)\end{array}$ & $\begin{array}{c}\text { Alanine aminotransferase } \\
\text { (ALT) } \\
(\mathrm{U} / \mathrm{L})\end{array}$ & $\begin{array}{l}\text { Total bilirubin level } \\
\text { (mg/dl) }\end{array}$ & $\begin{array}{c}\text { Hepatic glutathione } \\
\text { (GSH) } \\
\text { (nmol/mg protein) }\end{array}$ \\
\hline negative control group given DW & $51.25 \pm 2.72$ & $0.45 \pm 0.03$ & $12.25 \pm 0.2$ \\
\hline $\begin{array}{l}\text { Positive control group given APAP } \\
500 \mathrm{mg} / \mathrm{kg}\end{array}$ & $237.6 \pm 2.87 *$ & $0.88 \pm 0.1 *$ & $3.3 \pm 0.01 *$ \\
\hline $\begin{array}{c}250 \mu \mathrm{g} \text { ginger extract }+ \text { APAP } 500 \\
\mathrm{mg} / \mathrm{kg}\end{array}$ & $60.12 \pm 2.41 \#$ & $0.55 \pm 0.01 \#$ & $14.25 \pm 0.1 \#$ \\
\hline $\begin{array}{c}500 \mu \mathrm{g} \text { ginger extract }+ \text { APAP } 500 \\
\mathrm{mg} / \mathrm{kg}\end{array}$ & $55.2 \pm 2.32 \#$ & $0.5 \pm 0.02 \#$ & $13.72 \pm 0.11 \#$ \\
\hline $100 \mathrm{mg} / \mathrm{kg}$ AGE+ APAP $500 \mathrm{mg} / \mathrm{kg}$ & $56.2 \pm 1.88 \#$ & $0.54 \pm 0.03 \#$ & $13.22 \pm 0.2 \#$ \\
\hline $200 \mathrm{mg} / \mathrm{kg}$ AGE+ APAP $500 \mathrm{mg} / \mathrm{kg}$ & $53.1 \pm 2.1 \#$ & $0.48 \pm 0.01 \#$ & $12.75 \pm 0.1 \#$ \\
\hline $\begin{array}{c}500 \mu \mathrm{g} \text { ginger extract }+200 \mathrm{mg} / \mathrm{kg} \\
\text { AGE }+ \text { APAP } 500 \mathrm{mg} / \mathrm{kg}\end{array}$ & $52.3 \pm 2.2 \#$ & $0.46 \pm 0.02 \#$ & $12.5 \pm 0.2 \#$ \\
\hline
\end{tabular}

*significant versus negative control group $(\mathrm{p}<0.05)$

\#Significant versus positive control group $(\mathrm{p}<0.05)$ 


\section{Total bilirubin levels:-}

Total bilirubin level was significantly increased $(0.88 \pm 0.1 \mathrm{mg} / \mathrm{dlvs} 0.45 \pm 0.03, \mathrm{p}<0.05)$ in APAP group compared with control group. In groups given ginger extracts in doses of 250 and $500 \mu \mathrm{g}$ with APAP, total bilirubin levels were significantly lower compared with APAP alone $(0.55 \pm 0.01 \mathrm{mg} / \mathrm{dland} 0.5 \pm 0.02 \mathrm{mg} / \mathrm{dlvs} 0.88 \pm 0.1 \mathrm{mg} / \mathrm{dl}, \mathrm{p}<0.05$, respectively). Total bilirubin levels in mice given AGE in doses of 100 and $200 \mathrm{mg} / \mathrm{kg}$ with APAP were also significantly lower compared with those in mice given APAP alone $(0.54 \pm 0.03 \mathrm{mg} / \mathrm{dl}$ and $0.48 \pm 0.01 \mathrm{mg} / \mathrm{dlvs} 0.88 \pm 0.1 \mathrm{mg} / \mathrm{dl}, \mathrm{p}<0.05$, respectively. Given together, $500 \mu \mathrm{g}$ ginger extract and $200 \mathrm{mg} / \mathrm{kg}$ AGE significantly decreased bilirubin levels in mice given APAP $(0.46 \pm 0.02 \mathrm{mg} / \mathrm{dl} v \mathrm{vs} 0.88 \pm 0.1 \mathrm{mg} / \mathrm{dl}, \mathrm{p}<0.05)$

\section{Hepatic glutathione (GSH):-}

Levels of hepatic GSH decreased significantly in mice challenged with APAP compared with control group $(3.3 \pm 0.01 \mathrm{nmol} / \mathrm{mg}$ protein vs $12.25 \pm 0.2 \mathrm{nmol} / \mathrm{mg}$ protein, $\mathrm{P}<0.05)$. In mice ginger extracts in doses of 250 and $500 \mu \mathrm{g}$ with APAP, GSH levels increased significantly compared with APAP group $(14.25 \pm 0.1 \mathrm{nmol} / \mathrm{mg}$ protein and $13.72 \pm 0.1101 \mathrm{nmol} / \mathrm{mg}$ protein $v s 3.3 \pm 0.01 \mathrm{nmol} / \mathrm{mg}$ protein, $\mathrm{p}<0.001$, respectively).In groups given AGE 100 and $200 \mathrm{mg} / \mathrm{kg}+\mathrm{APAP}$, GSH levels were also significantly higher compared with that group given APAP alone $(13.22 \pm 0.201 \mathrm{nmol} / \mathrm{mg}$ protein and $12.75 \pm 0.1 \mathrm{nmol} / \mathrm{mg}$ protein $v s 3.3 \pm 0.01 \mathrm{nmol} / \mathrm{mg}$ protein, $\mathrm{p}<0.05$, respectively. Concomitant administration of $500 \mu \mathrm{g}$ ginger extract and $200 \mathrm{mg} / \mathrm{kg}$ AGE to mice given APAP significantly increased GSH levels compared with control group given APAP alone (12. $5 \pm 0.2$ vs $3.3 \pm 0.01 \mathrm{nmol} / \mathrm{mg}$ protein, $\mathrm{p}<$ $0.05)$.

\section{Discussion:-}

Acetaminophen (Paracetamol) is a commonly used safe and effective analgesic and antipyretic agent when used in therapeutic doses. However, when used at higher doses or misused by population, it could cause potential lifethreatening hepatotoxicity. Between 24 and 72 hours following overdose, signs of liver damage start to appear in the form of right upper quadrant abdominal pain and the hepatic transaminases ALT and AST rise to abnormal levels (32).

The present study observed that after 24 hours of oral administration of $500 \mathrm{mg}$ APAP to mice, serum levels of the hepatic enzyme ALT and the total bilirubin levels increased significantly compared to control mice with significant lowering of the hepatic antioxidant GSH. This is in agreement with other previous studies that reported rise oftransaminases and lowered hepatic GSH following paracetamol overdose $(31,33)$

Ginger is a commonly used herbal supplement with antibacterial, antioxidant, and antiinflammatory effects (34-35). The present study showed a dramatic hepatoprotective activity following oral administration of ethanolic ginger extract in addition to APAP as evidenced by the highly significant improvement of serum levels of ALT and bilirubin and hepatic levels of GSH. Our observation agrees with other previous studies in literature. Atta and his colleagues observed that oral administration of methanol extract of ginger improved degenerative histopathological changes induced by CCl4intoxication in liver (36).An in vitro study showed that zingerone, a ginger metabolite, inhibited lipid peroxidation in rat liver (37). Shanmugam et al. have been reported a protective effect for dietary ginger against oxidative damage in experimental diabetic rat tissues (38). Moreover, administration of ginger suppressed gene expression of the hepatic inflammation markers, TNF $\alpha$, and IL-6 and decreased NF- $\kappa$ B activity (39).

On the other hand, aged garlic, contrary to raw garlic, has been shown to have numerous beneficial biological effects antioxidant (40), anti-cancer (41) and immune stimulating effects of raw garlic (42). The present work showed that AGE exhibited a hepatoprotective effect against APAP-induced hepatic injury. Its concomitant intraperitoneal administration, in doses of 100 and $200 \mathrm{mg} / \mathrm{kg}$, improved serum levels of ALT and billirubin and hepatic glutathione content. Our observation is in line withJung et al. who reported that aged black garlic (ABG) exerts hepatoprotective effects against hepatic injury induced by carbon tetrachloride CCl4-and D-galactosamine, and high fat diet -induced hepatic steatosis (43). Similarly, Kim and his colleagues concluded that ABG has strong antioxidative properties and may protect against chronic alcohol-induced liver damage (44). Another study by Shaarawy et al. showed that garlic and silymarinhave a synergistic hepatoprotectiveeffct against N-nitrosodiethylamine (NDEA) and $\mathrm{CCl}(4)$-induced hepatotoxicity in male albino rats (45). Obioha et al. showed also that high dose of onion and moderate dose of garlic extracts ameliorated cadmium (Cd)-induced oxidative damage in rat liver by reduction of lipid peroxidation (46).In another model, $\mathrm{Pal}$ et al. reported that garlic protects against isoniazide and rifampin-induced hepatotoxicity (47). 
In conclusion, the present study revealed that Co-administration of ginger and aged garlic extract could prevents against paracetamol-induce hepatic injury

\section{References:-}

1. Larson AM, Polson J, Fontana RJ, Davern TJ, Lalani E, Hynan LS, Reisch JS, SchiØdt FV, Ostapowicz G, Shakil AO, Lee WM. Acute Liver Failure Study Group. Acetaminophen-induced acute liver failure: results of a United States multicenter, prospective study. Hepatology. 2005;42:1364-1372.

2. Budnitz DS, Lovegrove MC, Crosby AE. Emergency department visits for overdoses of acetaminophencontaining products. Am. J. Prev. Med. 2011;40:585-592.

3. Hinson JA., Reid AB., McCullough SS et al.: Acetaminophen - induced hepatotoxicity: role of metabolic activation, reactive oxygen/nitrogen species, and mitochondrial permeability transition. Drug Metab Rev., 2004; 36:805-822.

4. Manov I, Motanis H, Frumin I, et al: Hepatotoxicity of anti-inflammatory and analgesic drugs: ultra-structural aspects. ActaPharmacol Sin.; 2008; 27(3):259272.

5. R. S. Rivlin, "Historical perspective on the use of garlic," Journal of Nutrition, vol. 131, no. 3, pp. 951S-954S, 2001.

6. E. Ayaz and H. C. Alpsoy, “Garlic (Allium sativum) and traditional medicine,” TürkiyeParazitolojiiDergisi, vol. 31, no. 2, pp. 145-149, 2007.

7. W. L. Li, H. C. Zheng, J. Bukuru, and N. De Kimpe, "Natural medicines used in the traditional Chinese medical system for therapy of diabetes mellitus," Journal of Ethnopharmacology, vol. 92, no. 1, pp. 1-21, 2004.

8. Cemil B, Gokce EC, Kahveci R, Gokce A, Aksoy N, Sargon MF, Erdogan B, Kosem B (2016). Aged Garlic Extract Attenuates Neuronal Injury in a Rat Model of Spinal Cord Ischemia/Reperfusion Injury. J Med Food.;19(6):601-6.

9. Amagase H, Petesch BL, Matsuura H, Kasuga S, Itakura Y. Intake of garlic and its bioactive components. J Nutr. 2001;131:955S-62S.PubMedGoogle Scholar

10. Lawson LD. The composition and chemistry of garlic cloves and processed garlic. In: Koch HP, Lawson LD, editors. The Science and Therapeutic Application of Allium sativum L. and Related Species. Baltimore: Williams and Wilkins; 1996. p. 37-107.

11. Yoshikawa M; Hatakeyama S; Chatani N; Nishino Y; Yamahara J, Qualitative and quantitative analysis of bioactive principles in ZingiberisRhizoma by means of high performance liquid chromatography and gas liquid chromatography. On the evaluation of ZingiberisRhizoma and chemical change of constituents during ZingiberisRhizoma processing. YakugakuZasshi, 1993, 113(4), 307-315.

12. Newall CA, Anderson LA, Phillipson JD, Herbal medicines: a guide for health-care professionals, London, Pharmaceutical Press, 1996.

13. Govindarajan VS, CritRev FoodSci Nut., 1982, 17(1), 1-96.

14. Grant KL; Lutz RB, Ginger. Am J Health Syst Pharm., 2000, 57(10), 945-947.

15. Chang CP; Chang JY; Wang FY; Chang JG, J Ethnopharmacol., 1995, 48(1), 13-19.

16. Serthe J. A.A; Basile A.C; Oshioo T.T; Silva F.D; Mazella, A.A.G, Fitoterapia., 1992, 63(1), 55-59.

17. Iwu M.M (1993), Handbook of African Medicinal Plants CRS Press, Boca Raton, Fl, pp 116 -118.

18. IvankaStoilova, Albert IvanovKrastanov, A. Stoyanova, S. Gargova (2007). Antioxidant activity of a ginger extract (Zingiberofficinale). Food Chemistry 102(3):764-770 •

19. Hosseini A, Mirazi N (2014). Acute administration of ginger (Zingiberofficinale rhizomes) extract on timed intravenous pentylenetetrazol infusion seizure model in mice. Epilepsy Res. 2014; 108(3):411-9.

20. Ha SK, Moon E, Ju MS, Kim DH, Ryu JH, Oh MS, Kim SY. 6-Shogaol, a ginger product, modulates neuro inflammation: a new approach to neuroprotection. Neuropharmacology. 2012;63:211-23.

21. Shanmugam KR, Mallikarjuna K, Kesireddy N, Sathyavelu Reddy K. Neuroprotective effect of ginger on antioxidant enzymes in streptozotocin-induced diabetic rats. Food ChemToxicol. 2011;49:893-7.

22. Vishwakarma SL, Pal SC, Kasture VS, Kasture SB. Anxiolytic and antiemetic activity of Zingiberofficinale. Phytother Res. 2002 Nov;16(7):621-6.

23. Mascolo N; Jain R; Jain SC; Capasso F, J Ethnopharmacol., 1989, 27(1-2), 129-140.

24. Somanawat K, Thong-Ngam D, Klaikeaw N. Effects of curcumin attenuated hepatitis in mice with paracetamol overdose. Thai J Gastroenterol. 2012;13:43-49.

25. Committee for veterinary medicinal products paracetamol: Summary Report. 1999, London: European Agency for the Evaluation of Medicinal Products (EMEA). 
26. Fuhrman B1, Rosenblat M, Hayek T, Coleman R, Aviram M (2000). Ginger Extract Consumption Reduces Plasma Cholesterol, Inhibits LDL Oxidation and Attenuates Development of Atherosclerosis in Atherosclerotic, Apolipoprotein E-Deficient Mice. J Nutr.; 130(5):1124-31.

27. FatemehFallah-Rostami, MohaddesehAbouhosseiniTabari, BehzadEsfandiari, Hamid Aghajanzadeh, and ManijehYousefiBehzadi (2013). Immunomodulatory Activity of Aged Garlic Extract against Implanted Fibrosarcoma Tumor in Mice. N Am J Med Sci.; 5(3): 207-212.

28. Reitman S, Frankel SA (1957). A colorimetric method for the determination of serum glutamic oxaloacetic and pyruvic transaminases. Am. J. Clin. Pathol., 28(1): 56-63

29. Giulia Bortolussi, Lorena Zentilin, Gabriele Baj, Pablo Giraudi, Cristina Bellarosa, Mauro Giacca, Claudio Tiribelli, and Andrés F. Muro. Rescue of bilirubin-induced neonatal lethality in a mouse model of CriglerNajjar syndrome type I by AAV9-mediated gene transfer.FASEB J. 2012 Mar; 26(3): 1052-1063.

30. Doumas B. T., Kwok-Cheung P. P., Perry B. W., Jendrzejczak B., McComb R. B., Schaffer R., Hause L. L. (1985) Candidate reference method for determination of total bilirubin in serum: development and validation. Clin. Chem. 31, 1779-1789

31. Werawatganon D, Linlawan S, Thanapirom K, Somanawat K, Klaikeaw N, Rerknimitr R, Siriviriyakul P (2014). Aloe vera attenuated liver injury in mice with acetaminophen-induced hepatitis. BMC Complement Altern Med. 8;14:229.

32. Heard KJ (2008). "Acetylcysteine for Acetaminophen Poisoning". The New England Journal of Medicine. 359 (3): 285-92.

33. KanjanaSomanawat, Duangporn Thong-Ngam, NaruemonKlaikeaw(2013). Curcumin attenuated paracetamol overdose induced hepatitis World J Gastroenterol; 19(12): 1962-1967.

34. Bhandari U, Kanojia R, Pillai KK. Effect of ethanolic extract of Zingiberofficinale on dyslipidaemia in diabetic rats. J Ethnopharmacol. 2005;97:227-30.

35. Mallikarjuna K, Sahitya CP, Sathyavelu RK, Rajendra , W Ethanol toxicity: Rehabilitation of hepatic antioxidant defense system with dietary ginger. Fitoterapia. 2008; 79:174-8.

36. A. H. Atta, T. A. Elkoly,1 S. M. Mouneir, GehanKamel, N. A. Alwabel,2 and ShaimaaZaher. Hepatoprotective Effect of Methanol Extracts of Zingiberofficinale and Cichoriumintybus. Indian J Pharm Sci. 2010; 72(5): 564570.

37. Reddy ACP, Lokesh BR. Studies on spice principles as antioxidants in the inhibition of lipid peroxidation of rat liver microsomes. Molecular and Cellular Biochemistry. 1992;111(1-2):117-124.

38. Shanmugam KR, Mallikarjuna K, Nishanth K, Kuo CH, Reddy KS. Protective effect of dietary ginger on antioxidant enzymes and oxidative damage in experimental diabetic rat tissues. Food Chemistry. 2011;124(4):1436-1442.

39. Li X-H, McGrath KC-Y, Nammi S, Heather AK, Roufogalis BD. Attenuation of liver pro-inflammatory responses by Zingiberofficinale via inhibition of NF-kappa B activation in high-fat diet-fed rats. Basic and Clinical Pharmacology and Toxicology. 2012;110(3):238-244.

40. Borek C. Antioxidant health effects of aged garlic extract. J. Nutr.(2001);131:1010S-1015S.

41. Ishikawa H., Saeki T., Otani T., Suzuki T., Shimozuma K., Nishino H., Fukuda S., Morimoto K. Aged garlic extract prevents a decline of $\mathrm{NK}$ cell number and activity in patients with advanced cancer. J. Nutr.(2006);136:816S-820S.

42. Lau B.H., Yamasaki T., Gridley D.S. Garlic compounds modulate macrophage and T-lymphocye functions. Mol. Biother.(1991);3:103-107.

43. Jung Hyu Shin, \Chang Woo Lee, Soo Jin Oh, Jieun Yun, Moo Rim Kang, Sang-Bae Han, Heungsik Park, Jae Chul Jung, Yoon Hoo Chung, and Jong Soon Kang. Hepatoprotective Effect of Aged Black Garlic Extract in Rodents. Toxicol Res. 2014 Mar; 30(1): 49-54.

44. Kim MH1, Kim MJ, Lee JH, Han JI, Kim JH, Sok DE, Kim MR.Hepatoprotective effect of aged black garlic on chronic alcohol-induced liver injury in rats. J Med Food. 2011 Jul-Aug;14(7-8):732-8.

45. Shaarawy SM1, Tohamy AA, Elgendy SM, Elmageed ZY, Bahnasy A, Mohamed MS, Kandil E, Matrougui K.Protective effects of garlic and silymarin on NDEA-induced rats hepatotoxicity. Int J Biol Sci. 2009 Aug 11;5(6):549-57.

46. Obioha UE1, Suru SM, Ola-Mudathir KF, Faremi TY.Hepatoprotective potentials of onion and garlic extracts on cadmium-induced oxidative damage in rats. Biol Trace Elem Res. 2009;129(1-3):143-56.

47. Pal R1, Vaiphei K, Sikander A, Singh K, Rana SV.Effect of garlic on isoniazid and rifampicin-induced hepatic injury in rats. World J Gastroenterol. 2006 Jan 28;12(4):636-9. 